\title{
Assessing Knowledge in Dialogue Undergraduate Synopsis-based Oral Examinations at a Scandinavian Business School
}

\author{
Tackney, Charles T.; Strømgren, Ole; Sato, Toyoko
}

Document Version

Final published version

Publication date:

2009

License

CC BY-NC-ND

Citation for published version (APA):

Tackney, C. T., Strømgren, O., \& Sato, T. (2009). Assessing Knowledge in Dialogue: Undergraduate Synopsisbased Oral Examinations at a Scandinavian Business School. Department of Intercultural Communication and Management, Copenhagen Business School.

Link to publication in CBS Research Portal

\section{General rights}

Copyright and moral rights for the publications made accessible in the public portal are retained by the authors and/or other copyright owners and it is a condition of accessing publications that users recognise and abide by the legal requirements associated with these rights.

\section{Take down policy}

If you believe that this document breaches copyright please contact us (research.lib@cbs.dk) providing details, and we will remove access to the work immediately and investigate your claim. 


\title{
WORKING PAPER
}

\author{
2009, nr. 3 \\ Monday, August 30, 2009
}

\section{Assessing Knowledge in Dialogue: \\ Undergraduate Synopsis-based Oral Examinations at a Scandinavian Business School}

\author{
by \\ Charles T. Tackney, Ph.D., Associate Professor \\ Ole Strömgren, Senior Lecturer \\ Toyoko Sato, Ph.D. Candidate
}

Department of Intercultural Communication and Management

Porcelænshaven 18 A, DK-2000 Frederiksberg

Copenhagen Business School 
Note: this paper was submitted, presented, and received the "Carolyn Dexter Best International Paper" award from the Management Education Division of the August 2009 Academy of Management annual conference in Chicago. Comments or suggestions welcome; do not cite without permission from primary author.

\section{Contact Information:}

Charles T. Tackney, Assoc. Professor: +45-3815-3188, email: ct.ikl@cbs.dk, (Primary author). Ole Strömgren, Senior Lecturer (ret.): +45-3815-3176, email: oes.ikl@cbs.dk.

Toyoko Sato, Ph.D. Candidate: +45-3815-3188, email: tsa.ikl@cbs.dk

Department of Intercultural Communication and Management (IKL)

Copenhagen Business School

Porcelænshaven 18A

Frederiksberg, Denmark DK-2000

Telephone: +45-3815-3815 
Table of Contents

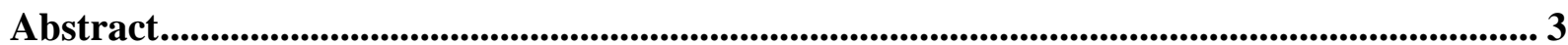



3.0: The Synopsis-based Oral Examination: a Process Summary ................................................. 6

4.0: S-OE Examinations in Program and Internationalized Contexts......................................... 8

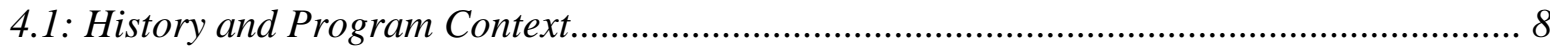

4.2: The Course Context - the 2008 Senior Year "Organizing International Business" Elective

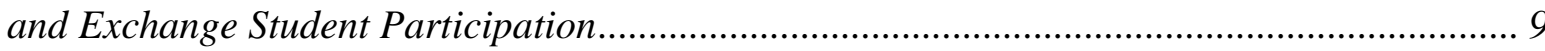

4.3: The S-OBE assessment - learning objectives, cognitive skills, and intersubjective dialogue

5.0: Practical and Administrative Considerations ...................................................................... 15



Appendix 1: Course Description, Learning Objectives and Lesson Plan for “Organizing International Business" ............................................................................................................................... 20

Table 1: The New Grading Scale ....................................................................................................... 28

Table 2: The Earlier 13-Point Grading Scale.......................................................................... 30

Table 3: Contrast Effect Between Cognitive Skills Assessment and the Intersubjective Student Performance Dimensions in Synopsis-based Oral Examinations ............................. 31

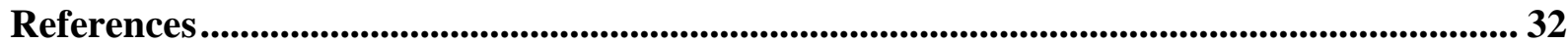




\section{Abstract}

We report a local or regional undergraduate examination form - the synopsis-based oral examination (S-BOE), as it is deployed in both large and small international management education programs at a Scandinavian business school. The S-BOE format is designed to assess student cognitive achievement in light of specified learning objectives through a focused presentation and dialogue involving an examiner and qualified censor, the latter being formally present to ensure process fairness for both examiner and student. It affords the examiner and censor the opportunity to explore student cognitive skills over the known range: unistructural > multistructural $>$ relational $>$ extended abstract (Biggs, J. 1999). Individuals as well as student project groups may be assessed using this approach. Administrative costs do not significantly exceed that of other course assessment formats: written reports or in-class group examinations. There are also interesting learning efficiencies; practitioner experience, reflection, and dialogue with students suggest that all students experience this examination format as a learning experience in itself, over a range of course-related knowledge issues and interpersonal skilling. Exemplary students manifest "dramatic knowledge" in those instances when they creatively display a comprehensive, reflective, and reflexive understanding of course material in presentation and subsequent intersubjective dialogue. The authors discuss important features of this undergraduate examination format that remain largely overlooked and under-appreciated in terms that regionally and locally contextualize international accreditation standards and process. At a time when economic, efficiency, and standardization concerns increasingly pressure educational institutions to adopt testing methods that are psychologically "distant” in respect to the instructor-student relationship, the synopsis-based oral examination is an interesting alternative suitable for small as well as large academic programs. 
Oral examinations are a common testing approach throughout the world. And, globally, tertiary educational programs face increasing pressures from various sources to rationalize, economize, and offer transparent, internationally “recognized” assessment standards and examination formats. Business schools and management education, broadly defined, seem particularly driven by such concerns. The Association to Advance Collegiate Schools of Business (AACSB), for example, claims a mission "to advance quality management education worldwide through accreditation and thought leadership” (AACSB, 2009). Potential member schools are subject to an accreditation process and periodic review, with a view towards “assurance of learning” (AACSB International Accreditation Coordinating Committee, November 20, 2007).

While knowledge is the goal of learning, and accreditation seeks assurance in learning, business education apparently remains fundamentally conflicted about the very "nature of knowledge” in business schools (Chia, R., Holt, R. 2008) and, in consequence, of its appropriate assessment. Chia and Holt challenge notions of "knowledge-by-representation” and, by implication, 'objective' assessment, concluding their paper with the hope that they "have made a case for encouraging a supplementary form of tacit knowledge realized through personal and imaginative habituation” (p. 483).

In this paper, the authors report on a local or regional undergraduate examination form the synopsis-based oral examination (S-BOE) - as it is deployed in both large and small international management education programs at a Scandinavian business school. We believe that assessment practices should indeed constitute the final assurance of learning outcomes. We further hold that assessment practices ought, in themselves, constitute a significant learning experience, ideally for all participants. In this respect, the paper contributes to this year's 
Academy of Management conference theme - "Green Management Matters" - by reflecting upon the notion of assessment itself and seeking to identify exemplary examination modes that authentically engage the whole person.

As we shall see, the S-BOE format, while apparently first developed out of efficiency and economic concerns, has a substantial, and as yet under-recognized, potential for student assessment that may bridge the 'nature of knowledge' tensions cited by Chia and Holt. Indeed, this approach returns to the student-teacher relationship a presentation/dialogue circumstance that is ultimately restorative of the ideals struggled for in the contemporary business education experience. At a minimum, this examination mode offers a choice to selectively complement testing in academic programs and the use of more formal, if more nominally accepted, “assurance of learning” methods that are psychologically "distant” in respect to the instructorstudent relationship. It is an interesting alternative that is suitable for small as well as large academic programs; in fact, the S-OBE format may well be as good as the educational examination ritual gets.

\section{0: Method}

The paper takes the format of an extended essay in six sections composed and written by experienced practitioners that wish to more thoroughly reflect upon the nature and function of a locally developed and, to date, regionally used examination format and present this format to the attention of a much broader audience. The temporal point-of-departure for this paper is the autumn 2008 senior year undergraduate elective course, “Organizing International Business,” taught at SBS in the Business, Language and Culture Program, the synopsis-based oral examination of 60 students at the end of this course, student grades, and an informal survey of the exchange students who made up nearly one-third of the total class. 
Having introduced the topic and method, the third section details the synopsis-based oral examination process, as a proper understanding of this exam format is essential. In the fourth section we review what is known about the history of this examination format, noting that this may be a curious instance of institutional efficiency and economic concerns combining - perhaps as a fortuitous, if unintended, consequence - to produce a very positive outcome in respect to improvement in examination practice.

We then consider, in section four, the S-BOE format in a specific program context and course context. We report home university and exchange student grades and note student comments on the exam format. We consider the examination in light of the learning objectives and cognitive skills categories used to assess the objectives. From a broader viewpoint of an intersubjective dialogue, it becomes apparent that the examination is, in itself, a valuable and under-appreciated educational experience for all parties.

In the fifth section, practical and administrative considerations are discussed. We conclude with a discussion of the assessment ideals embodied in this examination format.

\section{0: The Synopsis-based Oral Examination: a Process Summary}

Synopsis-based oral examinations are deployed at SBS in courses "that teach an eclectic mix of theory, method, and empirical content, often with different instructors in same course. In that situation, the opportunity of writing a synopsis enables and inspires the student to work towards creating some coherence across the different perspectives while accepting the legitimacy

of differences.”1 Approximately one-third of all courses at this school use this examination format.

\footnotetext{
${ }^{1}$ According to S.B., SBS Undergraduate Dean, January 4, 2009.
} 
Students compose and submit their synopses; there are no specific guidelines regarding synopsis content or format; page length is specified, usually a maximum of five double-spaced pages. Students may compose the synopsis together, as long as each student submits one synopsis. The synopsis, significantly, has no bearing on the student's final grade in the oral examination.

This submission signals staff that the student will be attending the exam. Staff then compose an examination list of eligible students, sending the list and synopses to the examiner and censor about one to two weeks in advance, who read them. The examiner has usually taught the course. The censor is an individual approved by the school or a related educational ministry. The censor's role is to ensure procedural fairness for both examiner and examinee. As previously noted, the grade is formally, and entirely, based strictly upon the oral examination experience alone, in light of the learning objectives for the course. Thus, students may work together in crafting and submitting a synopsis, each student retains the right to ask examiner and censor to disregard the synopsis entirely, should the student decide on reflection - after submission - that it is no longer a proper reflection of their learning.

On examination day, examiner and censor are in an assigned room with a list of students to be examined. The time allotted for each student is set by the administration; for course-based examinations this time period is currently 20 minutes per student. The 20 minute period includes:

1. a brief student presentation, which can be based on the previously submitted synopsis or not, depending on student inclination, and

2. a dialogue, during which time student, examiner and censor engage in a discussion that assesses, at a minimum, student knowledge of course material. 
3. The student is asked to leave the room. The examiner and censor decide on a grade, which is assigned in light of student performance relative to the stated learning objectives for the course.

4. The student is called back to the room for the grade award and a brief discussion of the examination.

\section{0: S-OE Examinations in Program and Internationalized Contexts}

\section{1: History and Program Context}

Having reviewed the exam process, we should note that this examination format, while very popular at the SBS, apparently did not originate here, although it is considered a traditional format for the culture and country. In fact, its specific origins, be they domestic or otherwise, remain somewhat murky. Knowledgeable colleagues suggest it may have come from the national university’s psychology, sociology or anthropology departments. Others believe it to be based upon national high school educational practices. There is, then, an apparently tacit presumption of the culturally given that has attached to the S-BOE examination format. As we shall see, internationalization, concretely evidenced by an influx of exchange students in a course who have never experienced this examination format, can shatter such presumptions, inviting a thorough reassessment of the previously assumed.

However introduced, the S-BOE appears to have found widespread use within the SBS as a result of rationalization efforts. At one time, particularly in language courses, it was common to have an exam that required the instructor to develop several different exam questions. A student would select one, and then spend a period of time, perhaps 30 minutes, to privately prepare this exam question. This required teacher preparation of many questions, a preparation room and a 
proctor's watchful compensation. The student would then face an oral examination in the presence of examiner and censor. At the SBS Master's level, the shift to the S-BOE format, particularly for courses with a "language" component, took place at the end of the 1990s. It is uncertain to what degree, if any, explicit pedagogical and/or test theory considerations informed these decisions.

At present, this exam form is used in about one-quarter to one-third of the courses assessments conducted at SBS. The “Organizing International Business” elective course, which is the subject of this paper's analysis, was designed for students pursuing either of two Programs at SBS: the Asian Studies or Business, Language, and Culture Programs. Both Programs are constituted by similar education goals, which have been previously characterized as "European Union Research-oriented Participatory Education” (EU-ROPE) (Tackney, Sato, Strömgren, 2007). Each year of both Programs has autumn coursework, followed by spring term research projects, which are usually group-based endeavors.

The academic "themes" for each of the three years of study are:

Year 1: Comparative cultural and social analysis

Year 2: Economic and cultural contexts of business enterprises and organizations Year 3: International and Global Corporate Strategies

\section{2: The Course Context - the 2008 Senior Year “Organizing International Business” Elective and Exchange Student Participation}

The authors were inspired to write this paper after several years of teaching and administration experience at this Business School. More recently, their reflection on undergraduate exchange student perceptions of the S-BOE, including student comments about 
their comparative sense of undergraduate education at SBS viz. their home university, suggested the present paper. ${ }^{2}$

SBS receives about 1,000 students annually from over 280 university exchange partners throughout the world. From teaching experience, the authors were aware that the S-OBE format presents exchange students with a puzzling new experience, generating a wide-range of reactions, and no small degree of serious concerns.

In the autumn 2008 term, approximately 78 students, one-third or more being exchange students, registered for a senior-year elective titled, “Organizing International Business”. The course description, learning objectives, and lesson plan are provided in Appendix 1.

The primary author has taught this course for three years. It involves a combination of lecture, discussion, and case analysis. The three case analysis submissions and discussions are planned and explained so that students, who may work in case groups, submit brief case analyses to the course website the evening before the case class. In class, any student group may be called upon to present their analysis. More than one group may be asked to present. Discussion follows until the case topic is exhausted. These sessions can be thought of as 'course embedded measures' that aid and encourage students in advance of the final examination.

The S-BOE format was mentioned from the first day and exchange students were particularly encouraged to persevere in course studies and preparation for the examination. In particular, students were encouraged to seek insight into the relationship between competing theory and data. And this encouragement took the form of Lonergan's (1958) critical realism epistemology, in which insight:

1. comes as a release from the tension of inquiry,

\footnotetext{
${ }^{2}$ The primary author is a dual citizen of the Republic of Ireland and the United States of America and, thus, an educational 'labor migrant' to Scandinavia, who had to learn the S-BOE format as an instructor.
} 
2. comes suddenly and unexpectedly,

3. is a function not of outer circumstances but inner conditions,

4. pivots between the concrete and the abstract, and

5. passes into the habitual texture of one's mind (pp. 3-4).

The examination week was Week 50 (December 8-12, 2009). Students examined each day were: 8, 8,12,14,18. A detailed explanation for the 12-point grading scale is given in Table 1 . Of these, 64 students (23 exchange students) submitted synopses and were scheduled for the final examination. There were 60 students who appeared when scheduled and received grades. Without exception, the S-BOE format was a first experience for the exchange students, and the grade distribution is given below.

$\begin{array}{lll}\text { Grade } & \text { Number of Students (Exchange) } & \text { ECTS grade equivalent } \\ 12 & 27(9) & \mathrm{A} \\ 10 & 9(3) & \mathrm{B} \\ 7 & 15(6) & \mathrm{C} \\ 4 & 7(0) & \mathrm{D} \\ 02 & 1(0) & \mathrm{E} \text { (minimal pass) } \\ 00 & 1(1) & \text { Fx (failure) }\end{array}$

During the examination week, after each examination - and once the grade had been declared and discussed - the examiner and censor generally queried exchange students about their sense of observed differences between this examination approach and that found in their home universities. Sometimes the students responded specifically about the examination, other times they commented more generally on differences between the educational institutions. Their 
observations are given in Appendix 2. These observations are informal and anecdotal, intended to provide the reader with exchange student impressions 'in situ'. Based on the exchange student grades and comments, indications are that presentation and dialogue aspects of the S-BOE work very well with students from diverse cultural and institutional backgrounds.

The informal student comments (See Appendix 2) indicate that their prior concern regarding the synopsis, and its lack of impact on grade outcomes, fails to 'carry over' to the other side of the actual examination experience. Instead, exchange students marvel at the exam experience: the intensity, the sheer drama of it, and the individual potential for an engaging intellectual encounter. The mere presence of the teacher, along with the role of the censor, makes a lasting impression. Students express interest in the exam format itself: "it makes us think.” The presentation period gives the students a rare opportunity to present material, as they understand it, to an examiner - and one who is neither the only teacher nor the sole arbiter of what constitutes 'correct' theory.

\section{3: The S-OBE assessment - learning objectives, cognitive skills, and intersubjective dialogue}

Each student is individually assessed in reference to the learning objectives for the course. These are:

"At the end of the course students should be able to

a. Describe the main historical themes of international management theory.

b. Account for recent theoretical developments in the field, especially concerning the construct of “innovation” and its business management across international borders. 
c. Compare and contrast the theories in question and apply them on specific cases, drawing on lectures and discussions with managers active in the process of organizing international business.” (From Appendix 1)

Each learning objective is phrased in a manner consistent with correlated cognitive skills (Biggs \& Tang, 1999). These range from simple retention and recitation of facts to the ability to theorize, generalize, hypothesize, and reflect. There is an implicit progression in cognitive skills from a. to c. in the stated objectives.

Student grades are determined by the extent to which students evidence these skills against the grade categories (see Table 1 ). ${ }^{3}$ At SBS, grades are assessed only in reference to the stated learning objectives. There is no forced curve distribution. In theory, if all students evidence "an excellent performance, displaying a high level of command of all aspects of the relevant material with no or only a few minor weaknesses,” then every student would earn a grade of 12 (A). In practice, this does not routinely obtain. However, the grade distribution for our particular course indicates many good examinations. Significantly, exchange students fared no worse than SBS students - who would in principle be more familiar with the S-BOE format. In fact, their grades appear rather better, aside from the one failure. ${ }^{4}$

The language employed in the cognitive-skills based learning objectives and grade explanation is wholly directed at the student performance. This is, of course, as it should be. However, from an intersubjective perspective, this is a very constrained and restricted 'view' of student performance. Thus, while these assessment measures help to provide objective terms and

\footnotetext{
${ }^{3}$ The examiner and censor are expected to achieve a consensus on the individual student grade. Formally, the censor holds a prerogative edge, should a insurmountable disagreement arise.

${ }^{4}$ Since we are dealing with the population of students who took the exam, inferential analysis to a hypothetical 'other' population is inappropriate.
} 
assurance of learning outcomes, they represent minimum threshold normative evaluations of an examination process that is, in fact, dramatically rich and potentially rewarding.

At its best, the S-BOE format does far more than assess one individual. It involves examiner and censor as collaborative hosts to a student presentation and dialogue that dramatically obliges the student to engage the audience with the student's presently known, selfunderstood, and dynamically structured insight(s) into complex course material. Neither presentation nor subsequent dialogue can be totally memorized, prepared, or anticipated. There is a lively dialogue of data, facts, history, and theory (often competing and/or complementary) between and among three individuals.

In form, the synopsis-based oral examination most closely resembles theatre. However, it also goes beyond art education and theatrical constructs of “dramatic knowing” (Rasmussen \& Wright, 2001). Rasmussen and Wright state, "In linguistic terms, dramatic knowing highlights a certain intentional, interactive, creative, and context-situated production of meaning.”

In practice, the examiner can be thought to proxy for the informed critic. The censor stands in for the public-at-large. The student, as performer, enacts a role that, while possible to rehearse, invariably becomes challenged, occasionally being overwhelmed, by the sheer set and setting of the examination encounter.

In function, the S-BOE format is an intersubjective educational encounter consisting of three distinct parties. For students, it has a striking impact, as indicated by the informal exchange student comments recorded in December 2008. In fact, it is a dramatic intersubjective encounter (Buber, 1971, Lonergan, 1958). And, once this function is apprehended in all its richness, the 
abject undersight of the grading process is starkly revealed. ${ }^{5}$ As Rasmussen and Wright wrote, dramatic knowing "tends to be poorly organised outside of the arts curriculum itself.”

\section{0: Practical and Administrative Considerations}

While the S-BOE form may indeed be "as good as it gets” for undergraduate assessment, there are a number of practical issues that need to be considered in its deployment. First, students initially find it difficult to believe that a synopsis submitted for an examination has no bearing on the grade outcome. This concern lasts no longer than one proper exam experience, as students quickly recognize the profound difference between their synopsis submission and the intensity of the actual oral examination. Too, they find, with experience, that there is a freedom in being able to ask a submitted synopsis be disregarded in light of post-submission preparation. Examiner and censor openness to this request is reinforcing and contributes to the present-moment dimension of the exam experience.

Students may find the dramatic nature of this examination format a psychological challenge. A student may become nervous to that extent that he or she is uable to proceed. Small gestures by the examiner and censor can help reduce anxiety - offering a glass of water, or recalling a class incident of common interest and humor. If student anxiety levels increase with S-BOE test experience, rather than decrease, then the student can be encouraged to rehearse the exam with friends, or - even - seek professional help to reduce anxiety levels. It has been the authors' experience that students invariably recognize the personal, academic, and future professional value of overcoming dysfunctional anxiety in this exam format.

\footnotetext{
${ }^{5}$ The use of 'undersight' is deliberate; assessments based strictly on cognitive skills fail to capture the exam format's richness. While not a fatal flaw, for grading purposes, it certainly cannot be an oversight, so it appears to be an institutionalized undersight.
} 
Instructors, too, sometimes have difficulties with the notion that a submitted document has no bearing on an examination outcome. Some may attempt to argue that a degree of influence is inevitable, that a good synopsis can move a bad oral performance up or, conversely, a good oral examination can suffer from a less than impressive synopsis. In practice, these considerations matter little more than initial student anxiety over synopsis submissions. A properly conducted S-OBE clearly results in outcomes that are not influenced by the synopsis. The synopsis is, functionally, merely a topical orientation to the oral presentation and subsequent dialogue, indicating the student has taken some position regarding the course.

Instructors, in turn, need prior training to successfully such examinations (the censor role is an excellent training mode). Each student, individually, has the same right to a fresh examination experience, even when examiner and censor may conduct 20 minute examinations for 15 to 20 times in a given day. This takes thorough knowledge of the course materials taught, a degree of interpersonal skills - necessary when students exhibit extreme anxiety, for example, and a healthy stamina.

Finally, as S-BOE exams proliferate within a program or school, variance in details may arise: synopsis length, presence or absence of suggested submission formats, content, targeted queries, examiner preferences for conducting the oral examinations, the role and function of the censors. These matters may require administrative oversight, based upon a properly functioning feedback mechanism from the students who experience the benefits and burdens of varied experiences.

Ultimately, some effort to comprehensively specify the taxonomy of tacit and other skills thought to be obtained from the program experience may become necessary. This taxonomy would nominally include the learning goals, objectives, assessment instruments and measures 
required for accreditation institutes approval. It may, however, also afford an opportunity for a program to go considerably beyond "mere” accreditation schemes.

In light of the preceding discussion, we might end this section with a contrast study of the cognitive-skills based assessment standards, on the one hand, against an inferred, and tentative, list of tacit and other skills that would characterize the larger 'dramatic knowledge' domain that actually appears manifest in the S-BOE format. We can pursue this based on the information available for the course that has been the focal point of this paper: "Organizing International Business.”

This contrast study is given in Table 3. Certainly, not every student achieves each of the points listed. However, the factors specified suggest that all students, regardless of actually grade outcome, equally share in a dramatic intersubjective dialogue with the educator responsible for their course, along with a public sector representative that is seated to ensure procedural fairness to both parties. Exchange students take the experience very seriously and claim to write home about it. Those that are able to take other courses and repeat this exam format get much better at precise, concise, presentation of their studied viewpoints.

\section{0: Discussion}

More than most, modern business and management educators recognize that internationalization and globalization processes result in a curious outcome: innovation and novel forms get 'pushed out' to regional and local event and invention discoveries (Moen \& Lilja 2005Doz, Barlett, Ghoshal, \& Birkinshaw, 2003; Santos \& Williamson, 2001). Similarly, the internationalization and globalization of business school accreditation activities should maintain 
a reasonable balance between the assurance of learning standards and a sympathetic willingness to learn from local and regional practices.

In light of these contrasting, complementary, and possibly competing concerns, the authors have crafted this paper to be a detailed presentation and analysis of the synopsis-based oral examination. It is an interesting examination format successfully being used at the undergraduate university level in both small and large-scale programs at a business school in Scandinavia. This format presents certain logistical challenges and requires a particular skills set in both examiner and censor. It affords an unusual opportunity for students to dramatically manifest their knowledge of course material through a direct presentation and dialogue with the course instructor. This experience directly - and quite physically - returns the teacher / assessor to the proper role as an educator. The examiner takes the path of being a sympathetic audience/critic able to observe and reward a student for knowledge acquired, insights gained, and able to present and discuss these in a reflective as well as reflexive manner.

Thus, the S-BOE examination itself becomes an additional and valuable learning experience, offering - in exemplary cases - manifestations of “dramatic knowledge” in intersubjective dialogue. The presence of a censor, the public representative, helps to ensure administrative/procedural fairness for both examiner and examinee. Should a censor with specific course and program knowledge be deployed to the exam, s/he could help to ensure a degree of validity to the individual exams, along with a degree of reliability throughout the course examination process. This step, which goes beyond the current national functions of the exam censor, could aid the incorporation of S-BOE formats to international/global business education accreditation procedures. ${ }^{6}$

\footnotetext{
${ }^{6}$ At present, censors may be external or internal, depending on the examination, and according to norms specified by a program's study board. The pool of external censors is established and maintained by a national registry.
} 
The S-BOE format appears to be novel in respect to its historical and geographical origins. It is also 'novel' in the sense that it is a counterpoint to contemporary trends toward standardization pressures that diminish teacher-student contact in the assessment process at the undergraduate level (a point made by several undergraduate exchange students in the informal survey, see Appendix 2). The S-BOE format presents an interesting, arguably unique, opportunity for dialogue and assessment. In this regard, we look on our paper as an exploration of 'hidden curriculum'. Yet, in contrast to the traditional analysis of power and subjugation associated with the phrase and legitimate analytical agenda (Margolis, 2001), our effort suggests that education of merit - potentially tractable merit - may co-exist with efforts to seek and achieve accreditation. Furthermore, the processes of internationalization and globalization need not result in abject abandonment of long-standing, traditional teaching practices. These historical processes can, given time, reflection, and collaboration, result in a greater reflexive awareness of the intrinsic merit of teaching practices that are not readily reducible to simplistic notions of 'objective standards'.

Practically, the S-OBE format is less time-consuming than small-group advisement. It is all the more productive because the interaction is time-constrained, yet fruitfully structured by the prior course material. It is not the only approach to student learning assessments and may be but one of several methods used in a program’s examination repertoire. Still, overall, the synopsis-based oral exam may be - to paraphrase Melvin Udall ${ }^{7}$ - about “as good as it gets” among currently known undergraduate examination formats.

\footnotetext{
Regardless of status, their current duties only extend to ensuring procedural fairness for student and examiner. Specialized course knowledge is not currently obliged. Adding this dimension for 'assurance of learning' assessments would appear to require policy adjustments at the national educational level.

${ }^{7}$ Melvin Udall, played by Jack Nicholson in the 1997 film, "As Good as it Gets," directed by James L. Brooks.
} 


\title{
Appendix 1: Course Description, Learning Objectives and Lesson Plan for "Organizing International Business”
}

\author{
Organizing International Business
}

\section{Course content:}

The course provides introductory and current research-based instruction for the study of international business: what it is, where the notion came from, and how the factors related to international business are changing modern business organization in light of globalization. Through lecture, readings, class discussion, case work and other educational means, students will acquire knowledge of theories about international business and how these have evolved over time. We explore the organization, structure, and communication implications that exist in modern multinational corporations (MNCs). We then examine internationalization strategies and issues of cross-border management, particularly concerning the management of innovation. Three case studies offer the opportunity for students to actively apply and steadily refine the knowledge they gain in the formulation of practical decisions aimed at achieving international business success.

\section{Learning objectives:}

At the end of the course students should be able to

d. Describe the main historical themes of international management theory.

e. Account for recent theoretical developments in the field, especially concerning the construct of "innovation" and its business management across international borders.

f. Compare and contrast the theories in question and apply them on specific cases, drawing on lectures and discussions with managers active in the process of organizing international business.

\section{Teaching methods:}

Class lectures and discussions will be related to a compendium and required text. Case study will, as stated above, offer opportunities for students to reflection upon and refine what they have learned through study - and this in team groups.

\section{Examination:}

A synopsis-based oral examination will be conducted at the end of the term. The synopsis should be no more than three double-spaced, typed pages in length. The topic of the synopsis is entirely up to the student; in general, the synopsis should seek to summarize the course material from the student's understanding and perspective of the stated learning objectives. Note that this synopsis must be properly submitted to be admitted to the examination. Thus, exchange students - in particular - are encouraged to identify the place where the synopsis need be submitted well in advance of the submission deadline.

While this synopsis must be submitted to attend the examination, it is important to recognize that the synopsis has no bearing on the oral examination grade itself. The oral examination lasts 20 minutes, inclusive of examiner/censor grade discussion and statement of grade to student. This 
examination format will be adequately discussed in class; exchange students are very welcome to register for this course and experience this novel Danish approach to course examinations.

Instructors: There are four instructors, one of whom is the course coordinator.

Required text: Morgan, G., Whitley, R., \& Moen, E. (2006). Changing Capitalisms? Internationalization, Institutional Change, and Systems of Economic Organization. Oxford: Oxford University Press. The text should be available in the CBS Bookstore.

Required Course Compendium: The course compendium will be available in the CBS bookstore. There have been several changes made in the compendium, so last year's will not be altogether current.

Case exercises and case feedback: There are three Case exercises offered in the course (see the schedule, below). To attend the final examination, each student is expected to have submitted either as an individual or group member - two Case exercises. This expectation is grounded in the knowledge that students who actively participate in the case studies perform better in the final synoptic-based oral examination.

Case exercises consist of submitting no more than three, double-spaced, typed pages that have been uploaded to the course folder on Sitescape by 10:00 pm the evening before the case class. Each and every group should be prepared to present their findings if called upon in class.

Presentations should not exceed 10 minutes, related discussion continues until evident closure obtains. There is no need for groups to prepare slide presentations - we seek case presentations that succinctly display critical insight, judgment, and deliberation for action. For this, the spoken word suffices.

Each student or group can receive written feedback from the coordinator on one of their case submissions. Please designate your choice on first page of the submitted case.

Case groups will be randomly assigned for the first Case if self-arranged groups are not already functioning. In this group-creation process, we intend to be particularly welcoming to exchange students, who are CBS guests. Subsequent case groupings are at will; groups should not exceed five students according to general principles for effective participation.

\section{LESSON PLAN WITH LESSON DATES, TIME, AND LOCATION}

\section{Latest version: Wednesday, September 17, 2008}

The lesson plan published in the Course Compendium lists the sequence and the week number of class sessions that will take place. It does not list the date, time, or the classroom locations; experience indicates these will almost certainly change and printed details in the Compendium result in confusion.

Class sessions, dates, time and location are provided here in this Lesson Plan. Basically, we meet every Thursday, 09:50 - 11:30 starting W37, 11 September 2008. Except Week 38, which starts at 08:00.

$\geq$ Class locations will, alas, vary. 
Class 1 / Week 37: Course Overview and Comparative Legal Ecologies of the Firm

Thursday, 11 September 2008; 09:50 - 11:30, PH407.

- Morgan, G. (2005). Introduction: Changing Capitalisms? Internationalization, Institutional Change, and Systems of Economic Organization. Chapter 1 in G. Morgan, R. Whitley, and E. Moen (Eds.), Changing Capitalisms? Internationalization, Institutional Change, and Systems of Economic Organization (Pp. 1-18). Oxford: Oxford University Press.

- Tackney, Charles T. (2008). “Where would you like to work, and why?” - Legal ecology Models for the Comparative Values Study of the Modern Enterprise. Paper presented to the Critical Management Studies Workshop 2008, Los Angeles. < This paper will be available in the Sitescape course folder one week prior to the first class. $>$

$>$ Groups formalized for the first Case exercise. The Case background and materials will be introduced and explained.

\section{Part I: The Internationalization Process}

Class 2 / W38: The evolution of international business and internationalization theories

Thursday, 18 September 2008; 8:00 -9:40, SP 113, IBM auditorium.

- Deeg, R. (2005). Path Dependency, Institutional Complementarity, and Change in National Business Systems. Chapter 2 in G. Morgan, R. Whitley, and E. Moen (Eds.), Changing Capitalisms? Internationalization, Institutional Change, and Systems of Economic Organization (pp. 21-52). Oxford: Oxford University Press.

- Griffin, R. and Pustay, M. (2005). Chapter 6, International Trade and Investment Theory. International Business - A Managerial Perspective. 4th edition. Prentice Hall, pp. 144- 175.

- Dunning ,J. H. (2001). The Key Literature on IB Activities 1960-2000. In A.N. Rugman and T.L. Brewer (Eds.), The Oxford Handbook of International Business, pp. 36-68, Oxford: Oxford University Press.

Class 3/W39: First Case: MiaP Machine Tools Corporation, Nagoya, Japan

Thursday, 25 September 2008; 09:50 - 11:30, KS71.

Case 1 Assignment: Read and prepared a labor union action plan for MiaP Corporation's union head. The case text is available on Sitescape. Hand in a maximum three pages summary of your solution in advance of the class.

Class 4/W40: The internationalisation process and internationalisation modes: Export, Import, FDI, Joint-Ventures, Alliances, Mergers and Acquisitions

Thursday, 2 October 2008; 09:50 - 11:30, Ks48 
- Hancké, B, and M. Goyer (2005). Degrees of Freedom: Rethinking the Institutional Analysis of Economic Change. Chapter 3 in G. Morgan, R. Whitley, and E. Moen (Eds.), Changing Capitalisms? Internationalization, Institutional Change, and Systems of Economic Organization (pp. 53 - 77). Oxford: Oxford University Press.

- Griffin, R. and Pustay, M. (2005). International Business - A Managerial Perspective. 4th edition. Prentice Hall. Chapter 12 \& 13.

- Björkman, I. \& M. Forsgren (2000). Nordic International Business Research: A Review of its Development, International Studies of Management and Organization, Vol. 30, No. 1, pp. 6-25

Class 5/W41: Internationalisation: How, why and where

$>$ Thursday, 9 October 2008; 09:50 - 11:30, SP212.

- Whitley, R. (2005). How National are Business Systems? The Role of States and Complementary Institutions in Standardizing Systems of Economic Coordination and Control at the National Level. Chapter 8 in G. Morgan, R. Whitley, and E. Moen (Eds.), Changing Capitalisms? Internationalization, Institutional Change, and Systems of Economic Organization (pp. 191 - 231). Oxford: Oxford University Press.

- Welch, L.S. \& R.K. Luostarinen (1988). Internationalisation: Evolution of a Concept, Journal of General Management, 14(2): 34-55.

- Whitelock, J (2002). Theories of Internationalisation and their Impact on Market Entry, International Marketing Review, 19(4): 342-347.

Week 42: no classes.

Class 6 /W43: Second Case: Cochran S.A.

Thursday, 23 October 2008; 09:50 - 11:30, SP212.

Case 2 Assignment: Read and solve the "Cochrane S.A." case at home. The text is in the Compendium. Hand in a maximum three pages summary of your solution in advance of the class.

Part II: The Structure of International Business

Class 7/W44: International strategy and cross-border management

Thursday, 30 October 2008; 09:50 - 11:30, SP207.

- Morgan, G., and S. Quack (2005). Internationalization and Capability Development in Professional Services Firms. Chapter 10 in G. Morgan, R. Whitley, and E. Moen (Eds.), Changing Capitalisms? Internationalization, Institutional Change, and Systems of Economic Organization (pp. 276 - 311). Oxford: Oxford University Press. 
- Bartlett, C. and Ghoshal, S. (1998), Managing Across Borders; The Transnational Solution. London: Random House, Chapters 1 (pp. 3-20) and 4 (pp. 65-81).

- Fleming, D. \& Søborg, H. (2003). Towards Reflexive Governance of Management-Labour Relations? Corporate Culture and Human Resource Management in Malaysia and Singapore. In Fleming, D \& Thörnqvist, C. (Eds.), Nordic Management-Labour Relations and Internationalization. Converging and Diverging Tendencies (pp. 23-47). Nordic Council of Ministers: Copenhagen.

Class 8/W45: Organising and structuring the MNC

Thursday, 6 November 2008; 09:50 - 11:30, SP212

- Whitley, R. (2005). Developing Transnational Organizational Capabilities in Multinational Companies: Institutional Constraints on Authority Sharing and Careers in Six Types of MNC. Chapter 9 in G. Morgan, R. Whitley, and E. Moen (Eds.), Changing Capitalisms? Internationalization, Institutional Change, and Systems of Economic Organization (pp. 235 276). Oxford: Oxford University Press.

- Hitt, M; Ireland, R. and Hoskisson, R. (2005) Ch. 11 in Strategic Management: Competitiveness and Globalization, Concepts and Cases. Thomson - South Western, Mason, Ohio.

- Westney, E. (2003) Geography as a Design Variable. In Birkinshaw et al., The Future of the Multinational Company. Chicester: Wiley.

Class 9: W46: International management of innovation

Thursday, 13 November October 2008; 09:50 - 11:30, SP212.

- Moen, E. and K. Lilja (2005). Change in Coordinated Market Economies: The Case of Nokia and Finland. Chapter 12 in G. Morgan, R. Whitley, and E. Moen (Eds.), Changing Capitalisms? Internationalization, Institutional Change, and Systems of Economic Organization (pp. 352 379). Oxford: Oxford University Press.

- Barlett, C., Ghoshal, S. Birkinshaw, J. (2003), 'Creating and Leveraging Knowledge: The Worldwide Learning Challenge’, Chapter 5 in Christopher A. Barlett, Sumantra Ghoshal, and Julian Birkinshaw, Transnational Management: Text, Cases, and Readings in Cross-Border Management, 4th ed., Boston: McGraw-Hill, pp. 456-465.

- Doz, Y, Santos, J. and Williamson, P. (2001), From Global to Metanational: How Companies Win in the Knowledge Economy, Chapters 1\&2, pp. 1-52.

Class 10/47: Aesthetics in the Global Marketplace 
Thursday, 20 November 2008; 09:50 - 11:30, Ks48.

- Kristensen, P.H. (2005). Modelling National Business Systems and the Civilizing Process. Chapter 13 in G. Morgan, R. Whitley, and E. Moen (Eds.), Changing Capitalisms? Internationalization, Institutional Change, and Systems of Economic Organization (pp. 383 414). Oxford: Oxford University Press.

- Jenkins, R. (1992). Culture, Status and Distinction. Chapter 6 in Pierre Bourdieu (pp. 128-151). New York: Routledge.

- Temporal, P. (2000).International Brand Acceptance in Asia / Considerations for Asian Companies to Compete in the International and Global Markets. Chapters 9 and 10 in Branding in Asia. The Creation, Development, and Management of Asian Brands for the Global Market (pp. 225-249). New York: Wiley.

- Boys Will Be Girls: Male Cosmetics and Beauty Mags Change Face of Youth (June 22, 1998). http://web-japan.org/trends98/honbun/ntj980619.html <This text will be available either through the Internet or copied to Sitescape. $>$.

Class 11/W48: Third Case: PG in Japan

Thursday, 27 November 2008; 09:50 - 11:30, SP212.

Case 3 Assignment: Read and solve the case "PG in Japan: The SK-II Globalization Project. Bartlett, Ghoshal, and Birkinshaw, pp. 466-484” at home. Hand in a maximum three pages summary of your solution in advance of the class.

Class 12/W49: Organizing International Business Course Summation

> Thursday, 4 December 2008; 09:50 - 11:30, SP212.

- Herrigel, G. and V. Wittke (2005). Varieties of Vertical Disintegration: The Global Trend Toward Heterogeneous Supply Relations and the Reproduction of Difference in US and German Manufacturing. Chapter 11 in G. Morgan, R. Whitley, and E. Moen (Eds.), Changing Capitalisms? Internationalization, Institutional Change, and Systems of Economic Organization (pp. 312 - 351). Oxford: Oxford University Press.

- Morgan, G. (2005). Institutional Complementarities, Path Dependency, and the Dynamics of Firms. Chapter 14 in G. Morgan, R. Whitley, and E. Moen (Eds.), Changing Capitalisms? Internationalization, Institutional Change, and Systems of Economic Organization (pp. 415 446) 


\section{Appendix 2: Informal Survey of Exchange Students, December 2008}

From December 8 - 12, the examiner and censors for the Senior Year elective

“Organizing International Business” conducted synopsis-based oral examinations with registered students who submitted synopsis on time. There were approximately 60 students examined (incidents of postponement due to illness arose). Approximately one-third of the class was exchange students. Grades were assessed in reference to stated learning objectives; there was no 'curve' used. One student failed, all the other students passed, with varying degrees of success.

After the grading was complete and the student was informed of the result, the examiner or censor informally asked each exchange student how he or she would characterize differences between their exchange experience and home university - either in general or in reference to the particular course. This Appendix lists these comments. The student's home school country is specified if known.

Exchange student comments:

- There are several instructors in this course. This:

- $\quad$ increases the points of view we get to (and have to) consider.

- reduces the 'one correct answer’ we always get back home with just one instructor.

- This exam compels more than the mere recitation of facts.

- We actually get to see and interact with professors at this school and in this exam, not just teaching assistants (U.S.A.).

- Class sizes are much smaller (Ireland, U.S.A., Australia, Baltic States, Germany).

- This test obliges us to think. 
- I have no prior experience in speaking about what I've learned in an examination, particularly in the presence of a professor.

- This Business School has a startling level of individual responsibility for study and performance.

- Where I'm from, everything is regulated and assessed: class attendance, participation, it is 'if/then' conditioned to grading and so it is constrained (Australia).

- It is important in this exam to take the initiative in presenting an understanding of the course.

- This school shows a greater emphasis on individual initiative than even (and especially) the U.S. school I'm from.

- This course presents the burden of organizing competing and complementary theory spanning different academic fields.

- We would never have such close contact with our professors (Germany).

- Home school is very 'traditional' as it obliges rote study and recitation in very large classes and with a very remote teacher (Baltic States).

- We never see the professor, s/he might respond to an email (Ireland). 


\section{Table 1: The New Grading Scale}

\section{The Grading Scale (from autumn 2007)}

\section{Understanding Marks Given According to the Grading Scale}

When attempting to understand the value of marks given in the system of another country, it is important not to automatically assume that the practice is similar to your own familiar system.

While some systems use a fixed distribution curve and expect all classes to fall within that curve, others specify the level of performance necessary for each mark. Grades in this country for each student are based on his or her specific level of performance; therefore "grading on the curve" is not a valid structure used at SBS.

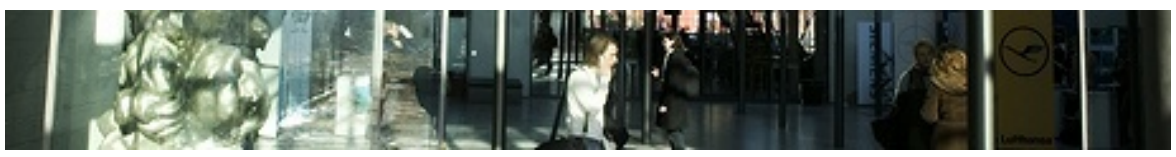

In this country, where education at all levels, including higher education, is regulated by the Ministry of Education, the marking scale and its use is described in a ministerial order which gives the following overview of the scale:

\begin{tabular}{|c|c|c|}
\hline $\begin{array}{l}\text { Grade } \\
\text { Mark }\end{array}$ & $\begin{array}{c}\text { Explanation of the } \\
\text { Mark }\end{array}$ & $\begin{array}{l}\text { Equivalent } \\
\text { ECTS } \\
\text { Mark }\end{array}$ \\
\hline 12 & $\begin{array}{l}\text { Is given for an excellent } \\
\text { performance, displaying } \\
\text { a high level of } \\
\text { command of all aspects } \\
\text { of the relevant material } \\
\text { with no or only a few } \\
\text { minor weaknesses }\end{array}$ & A \\
\hline 10 & $\begin{array}{l}\text { Is given for a very good } \\
\text { performance, displaying } \\
\text { a high level of } \\
\text { command of most } \\
\text { aspects of the relevant } \\
\text { material with only } \\
\text { minor weaknesses }\end{array}$ & B \\
\hline 7 & $\begin{array}{l}\text { Is given for a good } \\
\text { performance, displaying } \\
\text { good command of the } \\
\text { relevant material and } \\
\text { some weaknesses }\end{array}$ & C \\
\hline 4 & $\begin{array}{l}\text { Is given for a fair } \\
\text { performance, displaying } \\
\text { some command of the }\end{array}$ & D \\
\hline
\end{tabular}




\begin{tabular}{|c|c|c|}
\hline & $\begin{array}{l}\text { relevant material but } \\
\text { also some weaknesses }\end{array}$ & \\
\hline 02 & $\begin{array}{l}\text { Is given for a } \\
\text { performance meeting } \\
\text { only the minimum } \\
\text { requirements for } \\
\text { acceptance } \\
\text { (Lowest passing } \\
\text { grade) }\end{array}$ & $\mathbf{E}$ \\
\hline 00 & $\begin{array}{l}\text { Is given for a } \\
\text { performance which } \\
\text { does not meet the } \\
\text { minimum requirements } \\
\text { for acceptance } \\
\text { (Failure) }\end{array}$ & $\mathbf{F x}$ \\
\hline-3 & $\begin{array}{l}\text { Is given for a } \\
\text { performance which is } \\
\text { unacceptable in all } \\
\text { respects } \\
\text { (Failure) }\end{array}$ & $\mathbf{F}$ \\
\hline
\end{tabular}

The participation of external examiners from other institutions in almost all exams contributes to the stability of the scale and should prevent individual interpretation bias in marks.

Note: From the SBS International Office website. Specific school and nation references have been modified or deleted. 
Table 2: The Earlier 13-Point Grading Scale

\section{The 13-Point Grading Scale}

\section{Understanding Marks Given According to the 13-Point Scale}

This is the former grading scale. Students at SBS prior to Autumn 2007 received grades based on this:

13 given for exceptionally independent and excellent performance
Rarely Given

11 Is given for independent and excellent performance

10 Is given for excellent but not particularly independent performance

9 Is given for good performance, a little above average

8 Is given for average performance

7 Is given for mediocre performance, slightly below average

6 Is given for just acceptable performance

Minimum Passing Mark

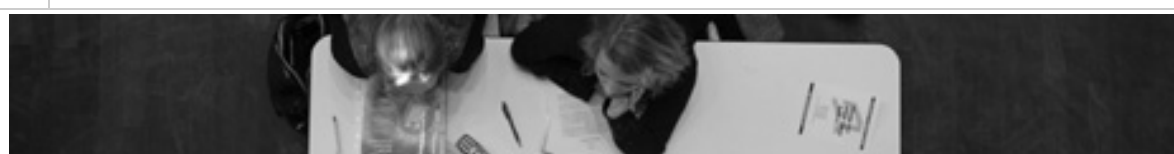

5 Is given for hesitant and not satisfactory performance

\section{Failure}

Is given for very hesitant, very insufficient and unsatisfactory

03 performance

Failure

$\mathbf{0 0}$ Is given for completely unacceptable performance

The jump from 13 to 11 emphasizes the fact that 13 is only to be given in rare and very exceptional cases. It should therefore not be compared to the top mark in most other systems.

The participation of external examiners from other institutions in almost all exams contributes to the stability of the scale and should prevent individual interpretation bias in marks.

Note: From the SBS International Office website. Specific school and nation references have been modified or deleted. 


\section{Table 3: Contrast Effect Between Cognitive Skills Assessment and the Intersubjective Student Performance Dimensions in Synopsis-based Oral Examinations}

\section{Learning objectives:}

At the end of the course students should be able to

a. Describe the main historical themes of international management theory.

b. Account for recent theoretical developments in the field, especially concerning the construct of "innovation" and its business management across international borders.

c. Compare and contrast the theories in question and apply them on specific cases, drawing on lectures and discussions with managers active in the process of organizing international business.

\section{Dramatic knowledge assessment: Tacit (and other) Skills Evidenced in the S-BOE format:}

- Creatively organizes course material and presents personal insights regarding course in a comprehensive and engaging manner.

- Maintains a proactive time-sense throughout exam, sensibly “managing” examiner and censor interruptions, query, and challenges.

- Actively listens to examiner and censor questions or comments, responding with appropriate references to the data, facts, history and theory that constituted course materials.

- Engages in dialogue with examiner and censor in such a manner that all participants authentically act and respond to each other in an equality of course material knowledge, notional discourse, agreement and/or respectful disagreement.

- Introduces extra-course material in a manner that raises the level of the entire examination experience for all participants < While this is not necessary for the highest grade, it does help to ensure one. This level of grade achievement was previously recognized in the national grading scheme. See the grade “13" described in Table 2. > 


\section{References}

AACSB International Accreditation Coordinating Committee (20 November 2007). AACSB Assurance of Learning Standards: An Interpretation.

http://www.aacsb.edu/accreditation/papers/AOLPaper-final-11-20-07.pdf .

Association to Advance Collegiate Schools of Business (2009). http://www.aacsb.edu/ . Text quoted on pg. 1 is taken from the Association's home page banner.

Barlett, C., Ghoshal, S. Birkinshaw, J. (2003), 'Creating and Leveraging Knowledge: The Worldwide Learning Challenge’, Chapter 5 in Christopher A. Barlett, Sumantra Ghoshal, and Julian Birkinshaw, Transnational Management: Text, Cases, and Readings in Cross-Border Management, 4th ed., Boston: McGraw-Hill, pp. 456-465.

Biggs, J., Tang, C. (1999). Teaching for Quality Learning at University. Berkshire: Open University Press.

Buber, M. (1971). I and Thou. New York: Free Press.

Chia, R., Holt, R. (2008). The Nature of Knowledge in Business Schools. Academy of Management Learning and Education. 7:4. 471-486.

Doz, Y, Santos, J. and Williamson, P. (2001), From Global to Metanational: How Companies

Win in the Knowledge Economy, Chapters 1\&2, pp. 1-52. Cambridge: Harvard Business School Press.

Lonergan, B. J. F. (1958). Insight: A Study of Human Understanding. New York, Harper \& Row. 
Margolis, E. (Ed.), (2001). The Hidden Curriculum in Higher Education. New York: Routledge.

Moen, E. and K. Lilja (2005). Change in Coordinated Market Economies: The Case of Nokia and Finland. Chapter 12 in G. Morgan, R. Whitley, and E. Moen (Eds.), Changing Capitalisms? Internationalization, Institutional Change, and Systems of Economic Organization (pp. 352 379). Oxford: Oxford University Press.

Rasmussen, B., and Wright, P. (February 12, 2001). The Theatre Workshop as Educational Space: How Imagined Reality if Voiced and Conceived. The International Journal of Education \& the Arts. 2:2. http://www.ijea.org/v2n2/index.html .

Ruskin, J. (1907). A Joy for Ever: The Two Paths. London: George Allen and Sons.

Tackney, C.T., Sato, T., Strömgren, O. (2007). Benchmarks in Tacit Knowledge Skills Instruction: European Undergraduate Research-Oriented Participatory Education (EU-ROPE). Management Education Division, Academy of Management, Philadephia. ( Note: Title has been abbreviated for site anonymity appropriate to double-blind peer review. ) 